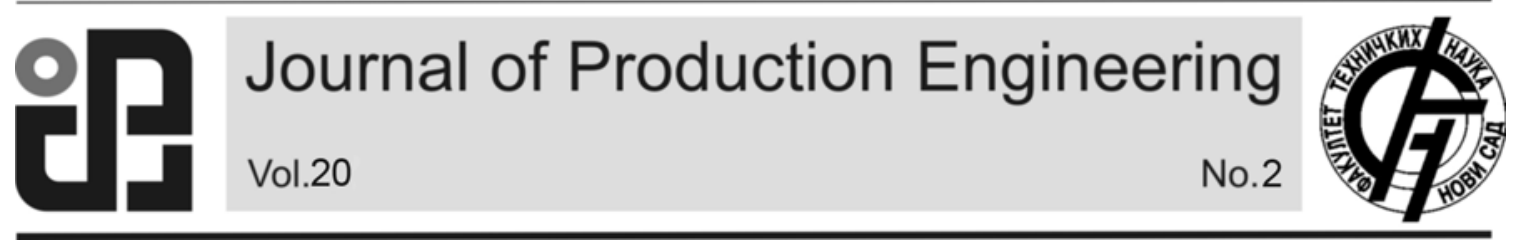

JPE (2017) Vol.20 (2)

Cica, Dj., Zeljkovic, M., Sredanovic, B., Tesic, S.

Original Scientific Paper

\title{
OPTIMIZATION OF MACHINING PARAMETERS WITH MINIMUM SURFACE ROUGHNESS FOR THREE-AXIS MILLING OF SCULPTURED PARTS
}

Received: 20 September 2017 / Accepted: 11 November 2017

\begin{abstract}
The objective of this study is to identify optimum machining parameters on surface quality of sculptured parts. The effect of various machining process parameters such as machining strategy, feed, depth of cut and spindle speed on surface roughness during three-axis end milling of sculptured parts have been studied by performing a number of experiments constructed according to standard Taguchi's L9 orthogonal array design matrix. Grey relational analysis method was used to find the optimal machining process parameters and analysis of variance was carried out to find the significance and contribution of each machining parameter on performance characteristics. Finally, confirmation test was conducted to indicate the effectiveness of this proposed method.
\end{abstract}

Key words: optimization, surface roughness, grey relational analysis

Optimizacija parametara obrade troosnog glodanja složenih površina u cilju obezbeđenja minimalne hrapavosti obrađene površine. Cilj ovog rada je određivanje optimalnih parametara obrade koji obezbeđuju minimalnu hrapavost obrađene površine. Razmatran je uticaj različitih parametara obrade, kao što su strategija obrade, brzina pomoćnog kretanja, dubina rezanja i broj obrtaja glavnog vretena, na hrapavost obrađene površine pri troosnom glodanju složenih površina. U radu je primenjen Tagučijev L9 ortogonalni plan za realizaciju eksperimentalnih ispitivanja, dok je siva relaciona analiza korišćena za rešavanje problema optimizacije. Za određivanje značaja pojedinih parametara na performanse karakteristike kvaliteta korišćena je analiza varijanse. Konačno, u cilju potvrde predloženog modela optimizacije proveden je i konfirmacioni test.

Ključne reči: optimizacija, hrapavost obrađene površine, siva relaciona analiza

\section{INTRODUCTION}

The rapidly development of the aerospace, automotive die moulding industries brings along the demand of new technological challenges related to the growing complexity of the products. Due to the improved functionality mechanical parts having sculptured surfaces are increasingly important in these industries. Sculptured surface machining, also called freeform surface machining is usually performing on a 3- or 5-axis CNC machining centers with a ball-nosed cutters. However, machining of sculptured surfaces has been a difficult problem addressed by numerous researchers. In this process, several problems such as over- or under-cuts, inappropriate cutting parameters, non-optimized tool paths etc., usually produce inadequate products that require expensive reworking which results in high production costs. Therefore, currently one of major areas of CAD/CAM systems is the representation and manufacture of mechanical parts having sculptured surfaces. In the field of sculptured surface machining, CAM systems allows implementation of various machining strategies (zigzag, true spiral, back forth, parallel spiral, high speed etc.) for roughing and finishing operation. A machining strategy is a methodology used to compute an operation with the aim of carrying out a geometrical entity in its final form [1]. Nevertheless, implementation and selection of a tool path generation strategy still remains an expert field. Appropriate selection can lead to considerable improvement of surface roughness and tool life, savings in machining time, etc., thereby leading to higher productivity and efficiency.

A large number of research papers about $\mathrm{CNC}$ machining of sculptured surfaces have been published. Gologlu and Sakarya [2] concluded that implementation and selection of cutting path strategies with appropriate cutting parameters had significant effect on surface roughness in pocket milling which is often encountered in plastic mould manufacture. Kim and Choi [3] proposed a machining time model that considers the acceleration and deceleration of the CNC machines and compare the machining efficiency of the different tool paths currently employed in molds and dies manufacturing. Ghani et al. [4] applied Taguchi optimization methodology for optimization of machining parameters in end milling process while machining hardened steel AISI H13 with TiN coated P10 carbide insert tool under semi-finishing and finishing conditions of high speed cutting. Mladjenovic et al. [5] analyzed the impact of the chosen machining strategy on roughness of flat surfaces machined with the ball end mill. Ramos et al. [6] analyze different finishing milling strategies of a complex geometry part containing concave and convex surfaces. Krimpenis and Vosniakos [7] developed optimization methodology for obtaining parameter values of sculptured surface parts rough machining. Oktem et al. [8] presents method for determination of optimum cutting parameters leading to minimum surface roughness in milling mod surfaces by coupling neural network and genetic algorithm. Oktem et al. [9] 
developed method for determination of the optimum cutting conditions leading to minimum surface roughness in milling of mold surfaces by coupling response surface methodology with a genetic algorithm. Li et al. [10] presents a multi-objective optimization approach, based on neural network, to optimize the cutting parameters in sculptured parts machining. Zain et al. [11] used genetic algorithm technique for estimation of the optimal cutting conditions in end milling machining process that yield the minimum surface roughness value.

The objective of this study is to identify the effects of tool path strategies for rough and finish machining of sculptured surfaces. Furthermore, second objective is to develop an optimization method in order to improve machining quality in $\mathrm{CNC}$ finish milling. The machining parameters considered were machining strategy, feed, depth of cut and spindle speed. The both objectives will be addressed by means of using Taguchi parameter design. The surface roughness optimization model was developed by grey relational analysis and a confirmation test was conducted to indicate the effectiveness of this proposed method.

\section{EXPERIMENTAL WORK}

Traditionally, dies and moulds are machined with a CNC machine where machining operation is usually decomposed in two main steps: rough and then a finish machining. The main objective of rough machining is to remove the maximum amount of raw material as soon as possible, leaving a coarse approximation to the final shape. Finishing operation objective is to meet the requirements of the final shape for best surface quality and outline precision. Since irregular scallops between finishing tool passes are inevitably generated on the machined surface, manual polishing of sculptured surfaces is often required to obtain the desired surface quality. While roughing as well as while finishing, implementation and selection of appropriate machining strategies with proper cutting parameters have significant effect on total production time, costs and product quality. Therefore, matters of support for selection of optimal machining strategy have their actuality in the environments of each CAM system.

Due to surface complexity optimal machining is significantly more complicated for sculptured surface parts comparing to prismatic parts. Sculptured surface parts usually demand long tool paths, which result in high machining times. There are numerous options to efficiently machine a sculptured surface parts which have different impact on cutting process elements wherefore a set of objective function must be defined. Owing to possibility to simulating various alternate machining scenarios and comparing them based on the obtained results the usage of CAM systems is considered today to be the most effective solution for technological preparation of production of sculptured surface parts. Therefore, first impact of machining strategy and machining parameters were examined in rough machining. In practice, in rough machining operations main objective is to achieve minimal costs of manufacturing removing as much material as possible in high removal rates. Thus, minimum machining time of a sculptured surface part is set as an objective. Simulation study was designed based on Taguchi L27 orthogonal array. Machining performance was investigated according to the following machining parameters: machining strategy, feed $(f)$, depth of cut (a) and spindle speed $(n)$. Levels of machining parameters are shown in Table 1. Part having sculptured surfaces used for simulation study is shown on the Fig. 1. Based on simulation analysis minimum machining time of $16 \mathrm{~min} 35 \mathrm{sec}$ is obtained for parallel spiral machining strategy, $f=650 \mathrm{~mm} / \mathrm{min}, a=$ $1.5 \mathrm{~mm}$ and $n=4000 \mathrm{~min}^{-1}$.

\begin{tabular}{|c|c|c|c|}
\hline \multirow{2}{*}{$\begin{array}{l}\text { Machining } \\
\text { parameter }\end{array}$} & \multicolumn{3}{|c|}{ Levels in coded form } \\
\hline & 1 & 2 & 3 \\
\hline $\begin{array}{l}\text { Machining } \\
\text { strategy }\end{array}$ & $\begin{array}{l}\text { True } \\
\text { spiral }\end{array}$ & $\begin{array}{c}\text { Parallel } \\
\text { spiral }\end{array}$ & $\begin{array}{l}\text { Morph } \\
\text { spiral }\end{array}$ \\
\hline $\begin{array}{c}\text { Feed, } \\
f[\mathrm{~mm} / \mathrm{min}]\end{array}$ & 350 & 500 & 650 \\
\hline $\begin{array}{l}\text { Depth of cut, } \\
a[\mathrm{~mm}]\end{array}$ & 0.5 & 1 & 1.5 \\
\hline $\begin{array}{c}\text { Spindle speed, } \\
n\left[\mathrm{~min}^{-1}\right]\end{array}$ & 3000 & 4000 & 5000 \\
\hline
\end{tabular}

Table 1. Design factors and their levels for rough machining

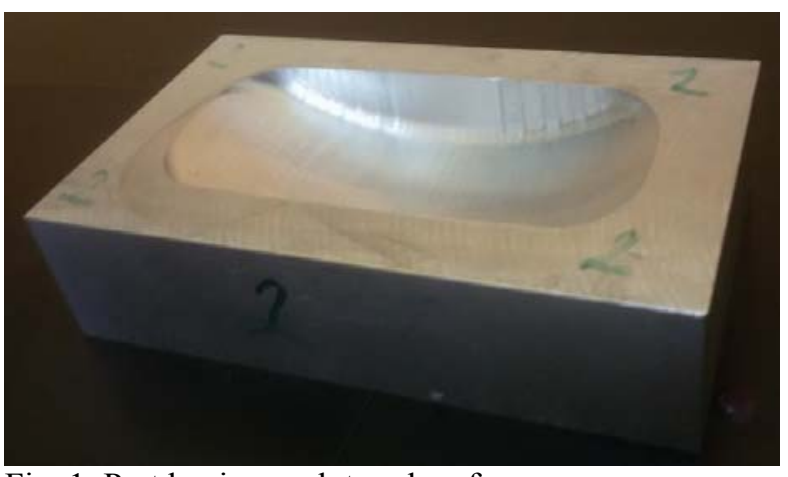

Fig. 1. Part having sculptured surfaces

Second objective of this paper is identify the effects of machining strategies and cutting parameters employed in finish machining of sculptured surfaces. In pocket milling which is often encountered in mould manufacture, the main demand is associated with minimum surface roughness in order to eliminate as far as possible manual surface grinding and polishing operation. In order to examine the influence of machining parameters on the surface roughness in finish milling, the experiments based on Taguchi L9 orthogonal array have been conducted. The machining parameters selected for the experimental work were machining strategy $(A)$, feed $(B)$, finish allowance $(C)$ and spindle speed $(D)$. Rough machining were performed with machining parameters which provides minimum machining time. The milling operations were performed on a 3-axis milling machine EMCO Concept Mill 450 equipped with a Sinumerik 840D CNC controller. The experiments were performed on machining aluminium alloy 7075-T6 with ball nose cutter of diameter $10 \mathrm{~mm}$. The surface roughness of the machined surface of each specimen was measured 
using Surftest SJ-210 Mitotoyo. Three measurements were conducted along the longitudinal and transverse direction for each specimen and the average surface roughness parameter values from those reading was recorded. Experimental plan consists values of machining parameters is shown in Table 2 while observed responses are shown in Table 3. Analyzing the results it can be concluded that, depending on the different machining strategy, different values of surface roughness were obtained for the same surface.

\begin{tabular}{|c|c|c|c|}
\hline \multirow{2}{*}{$\begin{array}{c}\text { Machining } \\
\text { parameter }\end{array}$} & \multicolumn{3}{|c|}{ Levels in coded form } \\
\cline { 2 - 4 } & 1 & 2 & 3 \\
\hline $\begin{array}{c}\text { Machining } \\
\text { strategy }\end{array}$ & Parallel & Radial & Contour \\
\hline $\begin{array}{c}\text { Feed, } \\
f[\mathrm{~mm} / \mathrm{min}]\end{array}$ & 150 & 250 & 350 \\
\hline $\begin{array}{c}\text { Depth of cut, } \\
a[\mathrm{~mm}]\end{array}$ & 0.1 & 0.2 & 0.3 \\
\hline $\begin{array}{c}\text { Spindle speed, } \\
n\left[\mathrm{~min}^{-1}\right]\end{array}$ & 5000 & 6500 & 8000 \\
\hline
\end{tabular}

Table 2. Design factors and their levels for finish machining

\section{GREY RELATIONAL ANALISYS}

Similar to the fuzzy set theory, the grey system theory is an effective mathematical model to deal with incomplete and uncertain information. In grey systems theory, a color spectrum from black to white is used to describe the degree of clearness of the available information. Black color means complete absence of information, whereas white color means having all the information. Grey color is used for intermediate level of information, i.e. for systems with partially known and partially unknown information. Therefore, grey color means the deficiency of information and uncertainty. The intensity of the shade of the grey determines the clarity of the available information, where lower intensity represent higher quality of the known information.

The grey relational analysis can be expressed in the following steps: (i) conversion of experimental data into normalized values, (ii) calculation of grey relational coefficients, (iii) generating grey relational grading. In the procedure of grey relational analysis, the first step is to normalize the data being input in the system in the range between 0 and 1, which is also called grey relational generation. Due to the different measurement units and scales of response attributes, pre-processing of all data in quantitative way into a comparability sequence is very important. The normalized type depends upon the characteristics of attributes including the smaller-the-better, larger-thebetter and nominal-the-better characteristic. The second step of grey relational analysis involves the determination of grey relation coefficient to represent the correlation between the desired and actual normalized experimental results. Finally, the grey relational grades were computed by averaging the grey relational coefficient corresponding to selected responses. The overall evaluation of the multiple process responses is based on the grey relational grade.
The grey relational grade indicate the degree of similarity between comparability sequence and the reference sequence. Hence, higher grey relational grade for particular comparability sequence shows that this comparability sequence is most similar to the reference sequence.

\section{RESULTS AND DISCUSSION}

According to the implementation steps of grey relational analysis method presented in the previous section, the experimental results for surface roughness in Table 3 were first normalized according to the "lowest-is-the-best" approach and then, deviations from the reference series were calculated. Afterwards, the grey relational coefficient for each machining response was calculated and listed in Table 3.

\begin{tabular}{|c|c|c|c|c|c|c|c|}
\hline \multirow{2}{*}{ No. } & \multicolumn{4}{|c|}{$\begin{array}{c}\text { Machining } \\
\text { parameter }\end{array}$} & $\begin{array}{c}R_{a} \\
{[\mu \mathrm{m}]}\end{array}$ & $\begin{array}{c}\text { Grey rel. } \\
\text { coeff. }\end{array}$ & Rank \\
\cline { 2 - 7 } & $A$ & $B$ & $C$ & $D$ & & & \\
\hline 1. & 1 & 1 & 1 & 1 & 0.446 & 1.000 & 1 \\
\hline 2. & 1 & 2 & 2 & 2 & 0.463 & 0.970 & 3 \\
\hline 3. & 1 & 3 & 3 & 3 & 0.537 & 0.856 & 5 \\
\hline 4. & 2 & 1 & 2 & 3 & 0.469 & 0.959 & 4 \\
\hline 5. & 2 & 2 & 3 & 1 & 0.449 & 0.995 & 2 \\
\hline 6. & 2 & 3 & 1 & 2 & 0.567 & 0.817 & 6 \\
\hline 7. & 3 & 1 & 3 & 2 & 1.528 & 0.333 & 9 \\
\hline 8. & 3 & 2 & 1 & 3 & 1.433 & 0.354 & 7 \\
\hline 9. & 3 & 3 & 2 & 1 & 1.513 & 0.336 & 8 \\
\hline
\end{tabular}

Table 3. Experimental results for finish machining and grey relational coefficients

In this study, it is observed that the experimental no. 1 has the highest grey relational coefficent among the nine experiments in Table 3 . The response table was obtained from the average value of the grey relational coefficent for each level of the control parameters in order to find the optimal level of each parameter. The optimal setting of control parameters is to select the level with higher value of grey relational coefficent. From the results shown in Table 4. the optimal level setting of four control parameters for minimizing surface roughness among the nine experiments are identified as surface finish parallel machining strategy, feed as $250 \mathrm{~mm} / \mathrm{min}$, depth of cut as $0.2 \mathrm{~mm}$ and spindle speed as $5000 \mathrm{~min}^{-1}$, represented as $A_{1} B_{2} C_{2} D_{1}$.

\begin{tabular}{|c|c|c|c|c|}
\hline \multirow{2}{*}{ Level } & \multicolumn{4}{|c|}{ Machining parameter } \\
\cline { 2 - 5 } & $\begin{array}{c}A \\
\text { Machining } \\
\text { strategy }\end{array}$ & $\begin{array}{c}B \\
\text { Feed, } \\
f \\
{[\mathrm{~mm} / \mathrm{min}]}\end{array}$ & $\begin{array}{c}C \\
\text { Depth } \\
\text { of cut, } \\
a \text { [mm] }\end{array}$ & $\begin{array}{c}D \\
\text { Spindle } \\
\text { speed, } \\
n \\
{\left[\mathrm{~min}^{-1}\right]}\end{array}$ \\
\hline Level 1 & 0.942 & 0.764 & 0.724 & 0.777 \\
\hline Level 2 & 0.924 & 0.770 & 0.755 & 0.707 \\
\hline Level 3 & 0.341 & 0.670 & 0.728 & 0.723 \\
\hline Max-Min & 0.601 & 0.100 & 0.027 & 0.054 \\
\hline Rank & 1 & 2 & 4 & 3 \\
\hline
\end{tabular}

Table 4. Response table for the grey relational coefficient 
Main effects plot of grey relational coefficent is drawn from response table, as shown in Fig. 2. The most influential factors affecting the surface roughness in sequence can be listed as: factor $A$ (machining strategy), factor $B$ (feed), factor $D$ (spindle speed) and factor $C$ (depth of cut). The interaction plot between the input parameters over calculated grey relational coefficent is shown in Fig. 3.
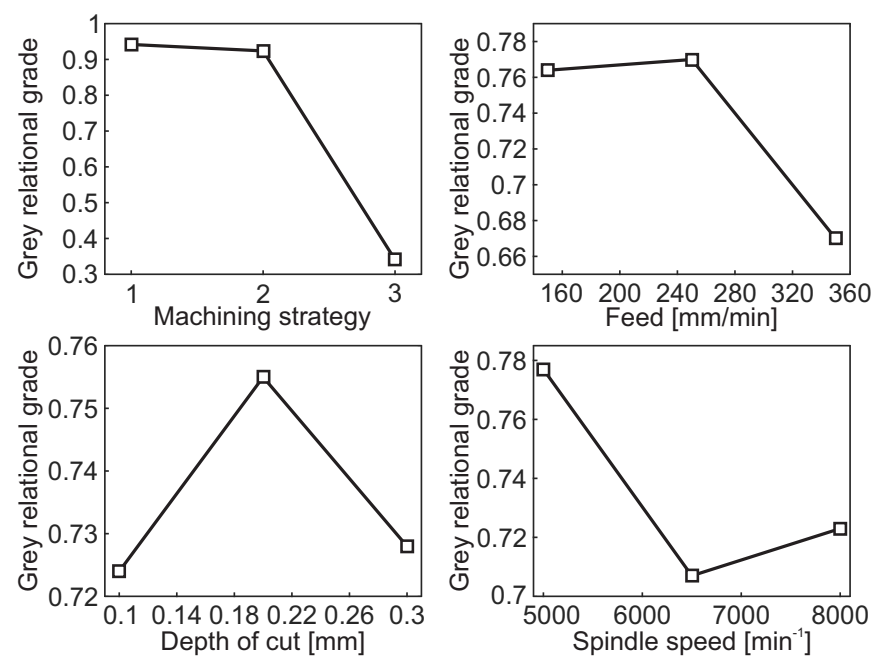

Fig. 2. Main effects plot for grey relational coefficient

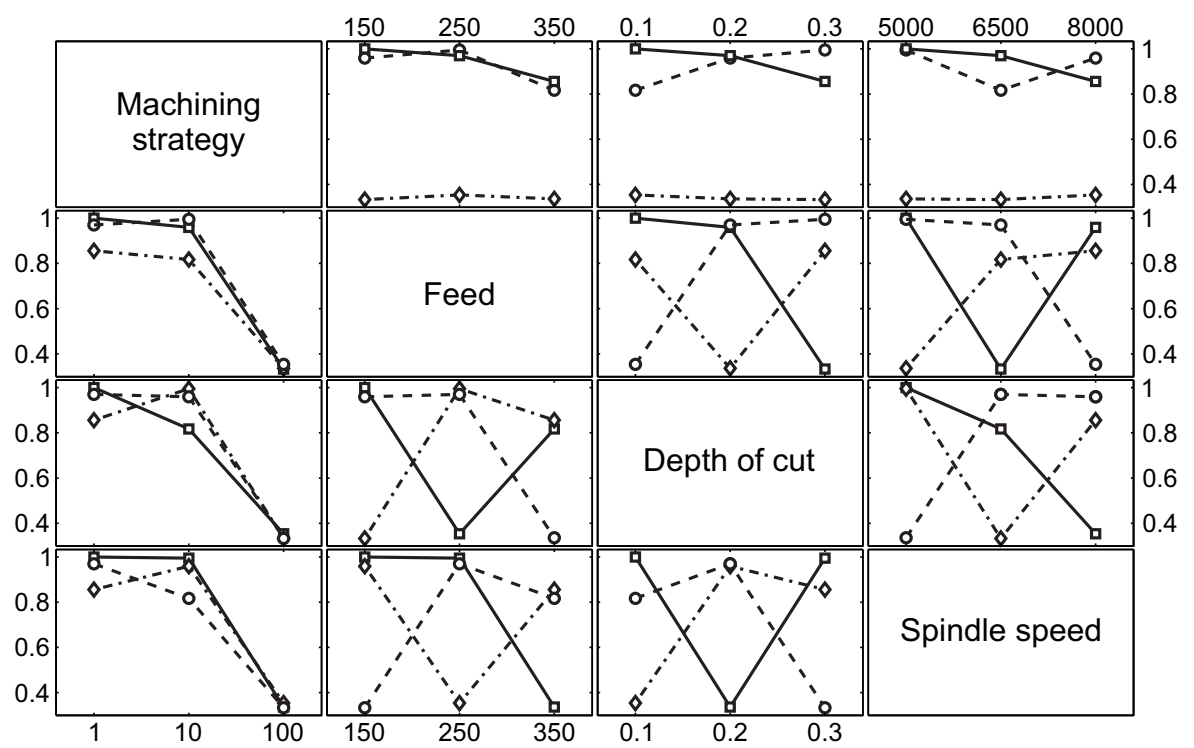

Fig. 3. Interaction plot for grey relational coefficient

In this study, the analysis of variance (ANOVA) is performed to investigate significance of machining parameters that affect the performance characteristics. An ANOVA table consists the parameters such as degree of freedom $(D O F)$, sum of squares $(S S)$, mean square $(M S)$, Fisher's ratio $(F)$ and probability value $(P)$. In this analysis, depth of cut having the least significant effect on surface roughness, hence it is pooled.

\begin{tabular}{|c|c|c|c|c|c|}
\hline Source & $D O F$ & $S S$ & $M S$ & $F$ & $P$ \\
\hline $\begin{array}{c}\text { Mach. } \\
\text { strategy }\end{array}$ & 2 & 0.70104 & 0.35052 & 405.33 & 0.0025 \\
\hline Feed & 2 & 0.01966 & 0.00983 & 11.37 & 0.0809 \\
\hline $\begin{array}{c}\text { Spindle } \\
\text { speed }\end{array}$ & 2 & 0.00813 & 0.00406 & 4.7 & 0.1754 \\
\hline $\begin{array}{c}\text { Residual } \\
\text { error }\end{array}$ & 2 & 0.00173 & 0.00086 & & \\
\hline Total & 8 & 0.73055 & & & \\
\hline
\end{tabular}

Results of ANOVA are presented in Table 5. and indicate that the machining strategy is most significant parameter, and feed is the next significant parameter that affecting the total performance characteristics. The error that may due to experiment determined from this ANOVA test was only $0.23 \%$, which is statistically acceptable.

\section{CONFIRMATION EXPERIMENT}

Finally, after obtaining optimal levels of four machining parameters a confirmation test was conducted to verify the improvement of surface roughness. Using optimal levels of machining parameters the minimal value of surface roughness was calculated as follows:

$$
Y=Y_{m}+\sum_{i=1}^{N}\left(\bar{Y}_{i}-Y_{m}\right)
$$


where $Y_{m}$ is total mean of experimental results for performance characteristic, $\bar{Y}_{i}$ is the mean of the experimental results at the optimal level and $N$ is the number of the machining parameters. The predicted surface roughness at optimal setting is found to be 0.413 $\mu \mathrm{m}$.

Finally a confirmation test was conducted to verify the improvement in the required performance characteristic that is surface roughness, using the optimal level of four machining parameters. Table 6 shows the comparisons of initial and optimal levels of machining parameters. The initial designate levels of machining parameters are $A_{1} B_{1} C_{1} D_{1}$ which is experiment no. 1 in Table 3 . Based on the confirmation experiments, for the final optimal combination of parameters $A_{1} B_{2} C_{2} D_{1}$ surface roughness $\left(R_{a}\right)$ is decreased from $0.446 \mu \mathrm{m}$ to $0.427 \mu \mathrm{m}$. Hence there is a significant improvement in surface roughness after optimization.

\begin{tabular}{|c|c|c|c|}
\hline \multirow{2}{*}{$\begin{array}{c}\text { Machining } \\
\text { parameter }\end{array}$} & \multirow{2}{*}{ Initial } & \multicolumn{2}{|c|}{ Optimal } \\
\cline { 3 - 4 } & & Prediction & Exp. \\
\hline Level & $A_{1} B_{1} C_{1} D_{1}$ & $A_{1} B_{2} C_{2} D_{1}$ & $A_{1} B_{2} C_{2} D_{1}$ \\
\hline $\begin{array}{c}\text { Surface roughness, } \\
R_{a}[\mu \mathrm{m}]\end{array}$ & 0.446 & 0.413 & 0.427 \\
\hline
\end{tabular}

Table 6. Initial and optimal level performance

\section{CONCLUSIONS}

First objective of this study is to identify the effects of different tool path strategies for three-axis milling of sculptured parts. Simulation study for rough machining was designed based on Taguchi L27 orthogonal array design matrix. Machining performance was investigated according to the four machining parameters (machining strategy, feed, depth of cut and spindle speed) each at three different levels, where minimum machining time is set as an objective. Furthermore, a method for surface roughness optimization using grey relational analysis has been successfully applied. Taguchi L9 orthogonal array design matrix was selected as experimental plan for the four machining parameters, namely machining strategy, feed, depth of cut and spindle speed. The analysis of variance revealed that machining strategy is the most influencing parameter that affect the performance characteristics. Finally, a confirmation test within the optimal machining parameters was conducted to indicate the effectiveness of grey relational analysis methodology. It is found that the performance characteristics, that is surface roughness, is improved using this proposed method.

\section{REFERENCES}

[1] Sun, G., Sequin, C.H., Wright, P.K.: Operation decomposition for freeform surface feature in process planning, Computer Aided Design Vol. 33, pp. 621-636, 2001.

[2] Gologlu, G., Sakarya, N.: The effects of cutter path strategies on surface roughness of pocket milling of 1.2738 steel based on Taguchi method, Journal of Materials Processing Technology Vol. 206(1-3), pp. 7-15, 2008.

[3] Kim, B.H., Choi, B.K.: Machining efficiency comparison direction-parallel tool path with contour-parallel tool path, Computer Aided Design, Vol. 34(2), pp. 89-95, 2002.

[4] Ghani, J.A., Choudhury, I.A., Hassan, H.H.: Application of Taguchi method in the optimization of end milling parameters, Journal of Materials Processing Technology, Vol. 145(1), pp. 84-92, 2004.

[5] Mlađenović, C., Kalentić, N., Zeljković, M., Tabaković, S.: The influence of milling strategies on roughness of complex surfaces, Journal of Production Engineering, Vol, 17(1), pp. 51-54, 2014.

[6] Ramos, A.M., Relvas, C., Simoes, J.A.: The influence of finishing milling strategies on texture, roughness and dimensional deviations on the machining of complex surfaces, Journal of Materials Processing Technology, Vol. 136(1-3), pp. 209-216, 2003.

[7] Krimpenis, A., Vosniakos, G.C.: Rough milling optimisation for parts with sculptured surfaces using genetic algorithms in a Stackelberg game, Journal of Intelligent Manufacturing, Vol. 20(4) pp. 447-461, 2009.

[8] Oktem, H., Erzurumlu, T., Erzincanli, F.: Prediction of minimum surface roughness in end milling mold parts using neutral network and genetic algorithm, Journal of Material and Design, 27(9), pp. 735-744, 2006.

[9] Oktem, H., Erzurumlu, T. Kurtaran, H.: Application of response surface methodology in the optimization of cutting conditions for surface roughness, Journal of Material Processing Technology, Vol. 170(1-2), pp. 11-16, 2005.

[10] Li, L. Liu, F., Chen, B., Li, C.B.: Multi-objective optimization of cutting parameters in sculptured parts machining based on neural network, Journal of Intelligent manufacturing, Vol. 26(5), pp. 891898, 2015.

[11] Zain, A.M., Haron, H., Sharif, S.: Application of GA to optimize cutting conditions for minimizing surface roughness in end milling machining process, Expert Systems with Applications, Vol. 37(6), pp. 4650-4659, 2010.

Authors: ${ }^{1}$ Assoc. Professor Djordje Cica PhD, ${ }^{2}$ Professor Milan Zeljkovic PhD, ${ }^{1}$ Research Associate Branislav Sredanovic MSc, ${ }^{2}$ Sasa Tesic B.Tech,

${ }^{1}$ Univeristy of Banja Luka, Faculty of Mechanical Engineering, Vojvode Stepe Stepanovica 75, 78000 Banja Luka, Bosnia and Hezegovina, Phone: +387 51 433000.

${ }^{2}$ University of Novi Sad, Faculty of Technical Sciences, Institute for Production Engineering, Trg Dositeja Obradovica 6, 21000 Novi Sad, Serbia, Phone: +38121450366.

E-mail: djordje.cica@mf.unibl.org milanz@uns.ac.rs branislav.sredanovic@mf.unibl.org sasa94tesic@hotmail.com 